\title{
Towards a New Approach to Authenticity in ELT
}

\author{
Soufiane Trabelsi \\ Sohar University, Sohar, the Sultanate of Oman
}

\begin{abstract}
The paper is a theoretical part of a doctoral research study that investigates the authenticity of Business English (BE) teaching materials used in a Tunisian higher education context. The notion of authenticity has been still problematic among English Language Teaching (ELT) researchers and applied linguists. The purpose of the study is attempting to suggest a localized approach to authenticity through the development of a new principled framework of authentic materials that will be valid for the Tunisian intermediate students of BE in the context of English as a foreign language (EFL). In more practical terms, the case study attempts to theorize a framework of authenticity based on surveying the literature on authenticity and subjecting it to a critical appraisal. Thus, an inductive research methodology approach is applied. The findings show that the authenticity of teaching materials is conditionally determined by surveying the profile of the students, their major stakeholders, and the context where materials are to be used. The implication of the study is that authenticity of the course materials is the result of the mediation of the needs and the demands of all the stakeholders and their context, bearing in mind that the teachers are likely to assume a primordial role in such mediation.
\end{abstract}

Keywords: authenticity, teaching materials, ELT, learner profile, stakeholders, needs, mediation

\section{Introduction}

Authenticity in English Language Teaching (ELT) is a very much debated issue as many educators, teachers, and researchers fail to distinguish and define different kinds of authenticity in language classroom. That is why a cursory reading of the relevant literature will highlight the confused and contradictory picture in which authenticity is perceived. There is much less agreement about what constitutes authenticity. There are also different types of authenticity and these are not always clearly distinguished. Authenticity has long been identified as a valid concept in many disciplines. How this concept is used depends on the context within a particular discipline, but the fact that the concept has been used and generalized in many disciplines implies the importance of authenticity. Therefore, differences in defining authenticity depend on the perspective from which the concept is viewed. These variations in defining the term reflect both its significance and ambiguity.

The controversy over the criteria whereby to define authenticity in ELT in general also applies to ESP as well since authenticity is a substantial component within ESP. Particularly with respect to materials design, authenticity of teaching materials is not agreed upon especially with regard to how to choose it, design it and implement it. The debate is still on the basis on which to create specialist materials or teaching materials input in conformity with the tenets of authenticity that is deemed a major component within ESP without which efficiency

Soufiane Trabelsi, lecturer, Ph.D., General Foundation Programme, Sohar University. 
is not sought or guaranteed.

Having introduced the topic of the present research study, it is worth defining the term and then developing the major claims available in the literature on authenticity and how each researcher treated this concept. The present research study will focus on authenticity of ESP teaching materials and particularly teaching Business English (BE), but it is also supposed to refer to other of authenticity since they complement the entire picture in which the concept is drawn.

\section{Definitions of Authenticity}

In Greek, authentikos means “original”, "primary”, and "at first hand”. The Random House Unabridged Dictionary (1993) provides explanations to authentic as "not false or copied; genuine; real; veritable; sharing the sense of actuality and lack of falsehood or misrepresentation” (p. 197); "having the origin supported by unquestionable evidence, authenticated, verified, or entitled to acceptance or belief because of agreement with known facts or experience; reliable; trustworthy" (p. 197). As seen, then, the word "authentic" carries connotations of authoritative certification, that an object or persons having the characteristics or source claimed or implied. Related words to the term authentic like "authentical, authenticate (to establish as genuine), authenticator (a person that authenticates), and authenticity (the quality of being authentic; genuine)" contribute to the unmistakable meaning of "authenticity" as conveying a quality of being "authentic” (p. 197).

\section{The Historical Background of Authenticity}

Most history books show that authenticity has a long history in language learning and that there are three main approaches that can be identified: First, there are "communicative approaches" according to which communication is both the objective of language learning and the means through which the language is taught. Second, there are "materials-focused approaches" according to which learning is centred principally round the text. Third, there are "humanistic approaches" which address the "whole" learner and emphasize the value of individual development (Mishan, 2005).

\section{“Communicative” Approaches}

These were used in the earliest colonial contexts when early civilizations discovered and conquered other lands, and they needed to communicate with speakers of other languages. It is proven by historians that second language teaching took place among the Sumerians from around 2700 BC (Titone, 1968, p. 5) while being conquered by the Akkadian Semites who then wanted to adopt the "local” language. The Sumerians' and later the Egyptian and Roman Empires' learning and teaching of languages can be assumed to have been authentic in spirit in the sense that the languages learned were acquired in non-educational contexts or situations and without specially developed language materials at that time. That was done instead via direct contact with the natives either through sojourns in foreign parts or, like what the Romans did, through the employment of a Greek-speaking tutor or slave (Titone, 1968, p. 5). Roman education was bilingual from infancy. Foreign language teaching in Roman times was assumed to be rather based on communicative purposes and authentic execution although this may not be for pedagogical reasons but for those of convenience (Mishan, 2005). Yet, the pedagogical factor in learning and teaching languages was the impetus for one of the best-recorded instances in 
history of a genuinely communicative and authentic approach to learning took place in the 16th century in the education of Michel Montaigne (1575):

In my infancy, and before I began to speak, he (my father) committed me to the care of a German (...) totally ignorant of our language, but very fluent, and a great critic in Latin. This man (...) had me continually with him: to him there were also joined two others (...) who all of them spoke to me in no other language but Latin. As to the rest of his family, it was an inviolable rule, that neither himself, nor my mother, man or maid, should speak anything in my company, but such Latin words as everyone had learned only to gabble with me (...) I was above six years of age before I understood either French or Perigordin (...) and without art, book, grammar, or percept, whipping, or the expense of a tear, I had, by that time, learned to speak as pure Latin as my master himself. (as cited in Mishan, 2005, p. 2)

The notion of communicativeness that is prevalent today dates back to the 1970's preceding a century of frenetic experimentation and development in language teaching methodology. The past hundred years had known a shift from academic approaches, to experimentation with so called "Natural" and "Direct" methodologies, to the first attempts at increasing technology for learning purposes. However, while all these approaches had an impact on the synthesis of Communicative Language Teaching (CLT), its real roots may be traced back to the advent of the new field of linguistics around the turn of the 20th century. This paved the way for the development of the linguistic branch of psycholinguistics which studies the cognitive faculties involved in language acquisition. Chomsky's (1965) Aspects of the Theory of Syntax, which distinguishes between speakers' competence (their knowledge of the language system) and their performance (their use of the language) can be considered as the trigger for the appearance of the communicative philosophy that has dominated in the last three decades of the 20th century (Howatt, 1984, p. 271).

Chomsky's notion of competence later developed into "communicative competence” which encompassed language use: "there are rules of use without which the rules of grammar would be useless" (Hymes, 1971, p. 15). Competence is now seen as "the overall underlying knowledge and ability for language use which the speaker-listener possesses (...) this involves far more than knowledge of (and ability for) grammaticality” (Brumfit \& Johnson, 1979, pp. 13-14). Simply put, an individual's communicative competence includes what he/she needs to know about the language in order to communicate successfully, that is, to get the desired outcome from the interaction. This notion of communicative competence constitutes the backbone of CLT.

The communicative philosophy, thus, means a reorientation of former teaching priorities, the teaching of communication via language, not the teaching of language via communication (Allwright, 1979, p. 167). In other words, effective communication was the objective and language was merely a means. It also meant that through the attempt to communicate using the language that the language was acquired. By the 1980's, the term "communicative" was the buzzword in all ELT coursebooks, although, as is often the case with commercial permutations of pedagogical approaches, communicative "templates” were sometimes used without their raison d'etre. Nevertheless, the realia creeping into the communicative coursebook heralded the advent of the use of authentic texts which eventually help return CLT to its “meaningful” roots (Mishan, 2005).

\section{Materials-Focused Approaches}

Like communicativeness, materials-focused approaches also date back to a long history including instances of the use of authentic texts for language learning occurring as early as the ninth century England where and when Latin was the international (European) language of communication. Yet, there were attempts to improve the 
education of the common people through the integration of the vernaculars-Old English, Anglo-Saxon—into the educational system as well as the translation of books into the vernaculars (some of the translations were done by King Alfred according to Pugh (1996, p. 160)). Both the texts and methods of learning may be defined as authentic; long stretches of text were read in what had been called a "holistic", reading for meaning approach (Pugh, 1996, p. 163). The teaching of Latin went through different stages over the centuries during which it was an international language, but by Medieval times, the teaching method used (in England and elsewhere) was the "scholastic method" which was based on breaking down words into their constituent parts. Learning the alphabet was thus the pre-requisite for reading and memorising sections of "primers". These were not texts particularly written for children, but were authentic texts which were mainly basic prayer books. This shows one of the controversial issues of the use of authentic materials for learning, their potential for political, cultural, and religious ones (Mishan, 2005).

A more liberal application of authentic materials or texts in language learning can be seen in the method developed by Roger Ascham (as cited in Mishan, 2005) in the mid-16th century according to which pupils translated the target language text into the mother tongue and then re-retranslated their versions into the target language. That was called the "double translation" method. Ascham used simple but authentic texts in this process - when applied to the teaching of Latin, for example, he used texts by Cicero. This technique is currently being revived in the context of cultural awareness-raising, where double translation at discourse level (rather than simply word/sentence level) is considered as a means of raising consciousness of cultural implications of linguistic choices (Pulverness, 1999, p. 9). The "inductive approach" (whereby readers infer grammar rules out of the texts) adopted by Ascham (and later by others) is also modern (Howatt, 1984, pp. 24, 35; Titone, 1968, p. 12). By inductive, Sweet (1899) meant that teachers should illustrate grammar with appropriate paradigmatic texts, which learners could then examine for more examples.

Sweet (1899) thought that the foundation of language study should be what he calls "connect texts" (this is in part a reaction against the dominance of the detached sentence in language teaching); "it is only in connected texts that the language itself can be given with each word in a natural and adequate context” (p. 164). He argued that connected texts are the best context for learners to establish and strengthen the correct associations between words, their contexts and their meanings (Sweet, 1899, pp. 164-173) and that only after it has been thoroughly studied and assimilated should the teacher draw out of it grammar points and vocabulary items (Sweet, 1899, pp. 192-193). The arguments that Sweet made for the use of authentic texts should seem modern in the sense that the practice persists to this day: "If we try to make our texts embody certain definite grammatical categories, the texts cease to be natural: they become either trivial, tedious and long-winded, or else they become more or less monstrosities" (Sweet, 1899, p. 192).

Like Ascham, Sweet also argued for the need for maintaining authenticity with lower level learners by exposing them to simpler language samples. He proposed that such levels be catered for by selecting genres which are simpler than others, for instance descriptive pieces (Sweet, 1899, p. 177). As such, he anticipated by almost a century, present-day arguments for authentic texts or materials: "Texts need not be 'grammatically sequenced' they need only to capture student attention and be comprehensible” (Krashen, 1989, pp. 19-20). Later in the 20th century, the dominating materials-focused approaches embodied many different theories of language acquisition. To illustrate, the "New Method" of the 1950's grew out of research into vocabulary frequency and 
the subsequent development of the "lexical distribution principle" (Howatt, 1984, p. 247). This tenet was materialized in a number of publications of grammar, dictionaries, and word-lists all containing limited and controlled lexical and grammatical materials.

Other methods followed like the "Oral Method", the "Situational Approach", the "Direct Method", and the "Audio-lingual Method", all of which relied on carefully structured materials and prescribed classroom activities or practices. The culmination of such approaches was an effective "cult of materials" (Howatt, 1984, p. 267) according to which "the authority of the approach resided in the materials themselves" (Howatt, 1984, p. 267) This can be considered as the beginning of a weakening phenomenon in ELT field that still exists today; of dependency on, and subservience to the textbook, still the teaching material of the choice for the majority of language teachers. As foreign language learning grew in importance through the progress of the century, it effectively developed into a modern industry accompanied by some evolving methodologies and the production of pedagogical literature. In other words, as the need for learning foreign languages for genuine communicative purposes increased, the authenticity of languages in terms of materials tended to decline (Mishan, 2005).

\section{Humanistic Approaches}

Another related group of approaches relevant to authenticity can be termed "humanistic" approaches which appeared periodically throughout history in reaction to more mechanistic teaching methods and approaches. This reaction to traditional approaches which emphasized rote-learning especially used in learning Latin and Greek during the 16th century gave emphasis to "language use” rather than "language usage”: "Every language must be learned by practice rather than by rules, especially by reading, repeating, copying, and by written and oral attempts at imitation” (as cited in Titone, 1968, pp. 14-15). Comenius also relied on an "intuitive approach" which is based on the sensory experience as the starting point for language learning. This approach mainly consists in the fact that learners respond to stimuli, objects and pictures and not to abstracts such as grammar rules.

These ideas always reoccur in a number of 20th century approaches which emphasize on exploiting the whole sensory repertoire of the brain during the learning experience. To illustrate, Suggestopedia (Lozanov, 1978), Total Physical Response (TPR) (Asher, 1977), The Silent Way (Gattegno, 1972), and Neuro-Linguistic Programming (NLP) (Bandler \& Grinder, 1975) all draw on cognitive psychology and are methods intended to exploit the potential of the human brain for learning more fully than traditional methods. What is common among these methods is their argument that the involvement of the "whole brain" can be seen as a realistic and interaction with the input. They also share the view of the importance of the use of problem-solving and discovery learning while teaching the language. Another common point they stressed is the notion of self-awareness, fulfilment, and communication capacity in all spheres of life. In other words, learners' awareness of themselves and of others should be enhanced in order to fully exploit their learning potential. This awareness specially applies to sense perception-visual, auditory, kinaesthetic, olfactory, and gustatory (Mishan, 2005).

No less one important approach among the humanistic ones is learner autonomy or self-directed learning because of its emphasis on, as well as its respect of, the individualism of the learner. Recently there has been a gradual shift in emphasis from teaching to learning and hence to the learner in particular. As indicated by the shift, it was language teaching that moved on, in the late 1980's, to "language teaching and learning” and culminated in 
the 1990's with "language learning". This change in emphasis shows that it is the learner who becomes at the centre of - and who finally controls - the learning process. This control factor as well as the responsibility that this brings with it is central to learner autonomy: "the main characteristic of autonomy (...) is that students take some significant responsibility for their own learning over and above responding to instruction” (Boud, 1988, p. 23). Learner autonomy is not an approach to learning but rather a condition involving "the internal psychological capacity to self-direct one’s own learning” (Benson, 1997, p. 25) through detachment, critical reflection, decision-making, and independent action (Little, 1991, p. 4).

It can be argued that the potential for autonomy is human universal (Little, 1999, p. 15) and that, in common with the other previously mentioned humanistic approaches, the ethos of learner autonomy simply acknowledges the undeniable individuality of the learning process, which means that people learn things at different rates, in different orders, using different strategies, and with different agendas (Mishan, 2005). In the language learning context, autonomy and authenticity are essentially symbiotic. The "ideal”, effective autonomous learner will use a wide variety of authentic sources in his/her learning and it is in an autonomous learning environment that such texts can be best explored. For example, some case studies on learner-experiences in self-instruction have discovered that especially at higher proficiency levels, learners benefit from interacting with authentic texts in autonomous modes (Fernàndez-Toro \& Jones, 1996, p. 200). Conversely, authenticity fosters autonomy:

Activities based around authentic texts (...) can play a key role in enhancing positive attitudes to learning, in promoting the development of a wide range of skills, and in enabling students to work independently of the teacher. In other words, they can play a key role in the promotion of learner autonomy. (McGarry, 1995, p. 3)

Exposure to and familiarity with authentic texts also help instil confidence in the face of the target language (Little, 1997, p. 231), an important factor in autonomous language learning as well as spurring learners towards authentic sources. These sources tend to stimulate learners to further independent discovery and learning. In truly autonomous learning, the authentic source text itself may be left to direct the learner: "These are uncharted waters; but a dip is all it takes to generate new energy for exploration” (Guillot, 1996, p. 152).

\section{The Concept of Authenticity in Multidisciplinary Sense}

Authenticity has long been identified as a valid concept in many disciplines. Fields such as law, business, literature, philosophy, folklore, language testing, psychology, archival science, diplomatics, computer security, and information systems will be reviewed with respect to the characteristics of authenticity in them.

Legally speaking, “authentic” means duly vested with all necessary formalities and legally attested; competent, credible, and reliable as evidence (Black, 1968). The term can be further clarified as a business concept. Within business law, authentication means verification of a document as truthful, genuine, or valid. More practically, in the security contract, authentication means the signing of a certificate of a bond by a trustee in order to identify it as having been issued under a specific indenture, thereby validating the bond (Rosenberg, 1993).

Like legal authentication, evidence is required in business and should be proved in certain formats. Similarly, in the realm of literature, and especially with reference to literary works, manuscripts, musical pieces, works of arts, and biblical manuscripts, authenticity is one of the powerful tools in establishing the originality and intention of creators. In his attempt to explain existentialism, Adorno (1973) maintained that the jargon of authenticity is the ideology of a language without any consideration of specific content. Thus, the critical issue that emerges 
from a discussion as philosophical as Adorno's is that we can arrive at a reasonable assessment of authenticity by the evidence from formal aspects, regardless of the content of the text.

The concept of authenticity also relates to the field of folklore. The identity and character of a folk have always been established by tracing the authenticity of texts. Generally speaking, the term "authentic" in folklore means original, genuine, or unaltered. To take an example, in Europe, which naturally favored efforts to legitimize the history and uniqueness of native languages, apparent folk materials constituted a major source for constructing authentic language and literature. To deeply examine the concept of authenticity in folklore is beyond the scope of this study, but there is a significant matter emerging in folklore which is the effort to render authenticity a scientifically verifiable entity. Accordingly, Bendix (1992) pointed that documenting the early efforts to ascertain authenticity by scientific methods is crucial for self-awareness in a discipline. Authenticity takes its meaning from the particular social or cultural context in which it is situated, and it is from within that context that the attempt to study it scientifically has been undertaken.

In diplomatics, the concept of authenticity is well established, Duranti (1989), for instance, argued that the origin of diplomatics is linked strictly to the need to determine the authenticity of documents. In this field, authentication refers to one or more signatories to an entire document or to a copy of the document, that is, the legal recognition that a signature is affixed by its creator and that a copy of a document conforms to the original. A document is "authentic" when it presents all the elements designed to provide it with authenticity (Duranti, 1991). A document is genuine when it is truly what it purports to be. Yet, an authentic document needs to comply with a special legal format. For example, a sentence is legally authentic when it is signed by a magistrate, and when it can be demonstrated that the signature is not false or counterfeit. Thus, being authentic means the presence of the requisites which provide authenticity. On the other hand, being genuine refers to the context or reality. That is, a document, whether it is genuine or not, can be authentic if it is presented in an appropriate format.

\section{Authenticity in English Language Teaching and Learning}

Authenticity is a major component within CLT especially with regard to texts used in order to convey meaning. It is always recalled when considering the selection of teaching materials, but the notion of authenticity is also accorded to language learners, tasks, and classroom situation. So, we talk of authentic learner, authentic task, and authentic class situation. A consensus, however, has not been reached on a precise definition of these terms, let alone the major concept of authenticity. What may be of importance, in this debate over authenticity, is whether the concept has the same application and implication both in ELT in general and ESP in particular. So, the present research study seeks to develop different views on authenticity, then different types of it and finally draws a brief comparison between the relevance of authenticity to ELT and ESP and its implications for teaching.

\section{Trends on Authenticity}

In reviewing the literature on authenticity in ELT area, one may deduce the existence of four trends which attempted to approach authenticity from different perspectives. To start with, there is a group of researchers and language theorists who tackled authenticity from a native speaker point of view, that is, for them authenticity is the native speakers' property. To develop this view, Wilkins (1976) considered authentic materials those which 
have not been specially written or recorded for the foreign language learning but which were originally directed at a native speaking audience. Similarly, Weijenberg (1980) shared the view that an authentic text is determined by the authenticity of the situation in which the language is produced and language is purely authentic when it is generated by a situation in which native speakers are conversing verbal communication. Naturally, native speakers would be the only acceptable speakers, and in such conversations the speakers do not concentrate on the language form per se, but use it only as a means of reaching a goal.

In parallel, Porter and Roberts (1987) contended that authentic texts are those texts which have not been specially prepared for language learners, and they are often delivered via technologies. Those texts also commit us to trying to replicate in class the roles that native speakers play in the authentic situation. This is because authentic texts are structured according to their purposes (Porter \& Roberts, 1987, p. 182). In the same vein, Harmer (1983) defined authentic texts (either written or spoken) as those which are designed for native speakers: They are real texts designed not for language students, but for the speakers of the language in question (p. 146).

Similarly, Bacon (1992), discussing what authentic materials may mean, argued that an authentic input is that which is created by and for a native speaker of the language in which is produced. This is also shared by Bacon and Finnemann (1990) saying that an authentic input is an input produced by and for native speakers of the target language. This is further confirmed by Swaffar (1985) who asserted that for purposes of the foreign language classroom, an authentic text, oral or written, is one whose primary intent is to communicate meaning. In other words, such a text can be one which is written for native speakers of the language to be read by other native speakers. This echoes Schmidt-Rinehart's (1997) view consisting in considering authentic materials as those developed for and by native speakers.

As for the second group, they relate/associate authenticity to/with the learners' profile, that is, authenticity for them is rendered, when learners' needs and interests are met or satisfied. In other words, judgements of authenticity in ELT in general are based bearing in mind the learners' character, personality, affect, abilities, needs, interests, motives, etc.. Among the proponents of this view, Spelleri (2002) stated that authentic materials have an high interest value because of their relevance and because there are three layers of learning embedded within them: language learning (the structure and vocabulary), cultural insights (way of living or customs), and practical application (using the item in the way it was intended). Such materials reflect the learners' reality and bridge the gap from the classroom lesson to real life by incorporating names, places, events, and factual information that can actually be used by the learner to enrich his life, completely aside from initial benefits of language learning. Learners have to deal with the language of brochures, announcements, maps, forms, applications, guidelines, and schedules. Exposure to authentic language means that learners will improve their skills and strategies used to manage real issues and matters and these should be spotlighted and built upon by the instructor in order to achieve much faster results than would naturally occur if the learners were just coming across the authentic materials and unconsciously developing strategies on their own, outside of the class.

Hutchinson and Waters (1987), in defining authenticity, argued that it is not a characteristic in itself: It is a feature of a text in a particular context. A text can only be truly authentic, in other words, in the context, for which it was originally written. They advised us that we should not be looking for some abstract concept of authenticity, but rather the practical concept of fitness to the learning purpose (Hutchinson \& Waters, 1987, p. 159). Within the 
same respect, Clarke (1989) goes a bit further than that, especially when he saw the notion of authenticity as something increasingly becoming relative and related to specific learners' needs and less concerned with "the authentic" nature of the input materials. For him the communicative authenticity of teaching materials may be seen as a matter of what learners do, or are required to do, with those materials. This is also maintained by Candlin and Breen (1979) who considered authenticity something of paramount importance and little if anything to do with the nature of the materials themselves. They predicated authenticity upon the extent to which materials evolve from the learning process and are thus sensitive to differential needs.

With reference to teaching English for Specific Purposes, Bhatia (1994), approaching the notion of authenticity of ESP materials, advocated an adoption of a generic perspective in ESP, i.e., the use of authentic discipline-specific texts as input to designing teaching materials and more, importantly, the need to maintain "generic integrity" in the ESP classroom. The generic perspective, or the use of authentic texts, currently underlies the theoretical base for the selection and preparation of ESP materials. So, the message that Bhatia wanted to convey here is that we should expose our ESP learners to subject-specific or specialist materials as well as methods that best suit their context, their background, their profile, and their future. Within the same vein, Dumitrescu (2000) contended that in the field of ESP, by its narrowly defined nature, requires the use of content materials that are not always constructed for the purpose of language learning. For him, the two factors that influence the final decision of the materials designer of what to incorporate into specific language tasks are applicability and adaptability. As for applicability, it refers to the relation between the learners' career goals and the kind of materials used, that is whether they address individual needs of the learners with respect to their domains or professional realities. Concerning adaptability, it relates to the ease of task design and ease of text manipulation. Materials need to contain linguistic elements applicable to the general objectives of the course and the learners' individual goals as well as practical skill-building requirements. The more relevant the materials are to the learners' professional activities, the more effective learning becomes. It is worth noting that tasks addressing immediate communication needs are likely to be perceived as more significant than tasks addressing skills that may be used at a later stage in the learner's career.

As a final view within this group, Hopkins (1998) considered authentic materials, as opposed to "cooked for English study”, preferable for task-based learning. Specifically beginning learners will have to utilize language texts aimed at satisfying personal and social needs. Yet, by intermediate level, learners should begin to explore "authentic" materials that fit their individual interests and requirements. Accordingly, learners increasingly individualize their study or course. They learn the language because of a felt need which expresses itself in some practical application-trading, socializing, negotiating, or other thing. Finally, they are successful in their learning to the degree that they fulfill their felt needs, and achieve a self-sustaining, sympathetic relationship with the people and culture of that language.

The third group of scholars who hold a distinct view on authenticity are headed by Widdowson (1978, 1979, 1990) assuming that authenticity is a matter of interaction with language paving the way for a positive response towards it. It is realized by learners themselves and it is never an available a priori phenomenon. Widdowson (1979), taking a different view on authenticity from the first group mentioned above, put it plainly by saying that authenticity is not considered as a quality residing in instances of language but as a quality which is bestowed upon them, created by the response of the receiver. Authenticity is not deemed as something there waiting to be 
noticed, we realize it in the act of interpretation (Widdowson, 1979, p. 165). Among the supporters of this view, Lee (1995), in his distinction between text authenticity and learner authenticity, assumed that text authenticity is determined by the origin of the materials, learner authenticity by appropriate and positive psychological responses to the learner's interaction with the materials. Learner-authentic materials are mainly learner-centered, and can serve effectively to promote learners' interest in language learning.

This suggests that authenticity can only be achieved when there is an agreement between the text's intention and the learner's interpretation. This reminds us of Widdowson's argument demonstrated as the following: "authenticity depends on a congruence of the language producer's intentions and the language receiver's interpretation. This congruence is being affected through a shared knowledge of conventions" (Widdowson, 1979, p. 166). "Perhaps”, wrote Breen (1985), “the criteria to guide the teacher’s selection and use of texts (both written and spoken) reside initially, not in the texts themselves, but in the learners” (p. 63).

As a final view within the same group, Tubtimtong (1994) argued that especially in an inter-disciplinary class, authenticity of materials must be sought in some aspects of the course such as the learner's response, in the interpretative strategies they bring to bear on communicative exchange, and in the types of tasks and activities that take place in the learning situation.

As a fourth group, there are researchers and language experts who consider authenticity as a depiction, a reflection of reality. For them, authenticity means real communication used for social purposes as enacted in our daily life between real speakers or users of the language. This trend is shared by Nunan (1989) who contended that authentic materials are materials which have not been specifically produced for the purposes of language teaching but for social ones. For Linder (2000), the term "authentic materials" can be an elusive one because it may refer to authentic English language items that are used as realia and as texts. By orienting the selection and use of authentic materials as texts (“a verbal record of a communicative act” (Brown \& Yule, 1983, p. 190)) rather than as realia, teachers use authentic materials as teaching tools more effectively. When used as realia, authentic menus for examples, suggest a real situation in the classroom; they become complementary to the lesson content. However, when used as texts, these same menus become rich resources for exposing students to language as it used in reality within the English culture; they become the central focus of a lesson.

As another similar attitude toward authentic materials, Peacock (1998) took them as being documents which have been produced to fulfill some social purposes in the language community. Morrow (1977, p. 13), who goes further than that in determining authentic texts, assumed that they are a stretch of real language produced by a real speaker or writer for a real audience and designed to convey a real message of some sort. That is why, for Morrow (1977, p. 26), one feature of authentic language should be noted, namely, that with rare exceptions it is not simplified to take account of the linguistic abilities of the addressee. Finally, Grellet (1981) shared the view that "authenticity means that nothing of the original text is changed and also that its presentation and layout are retained” (p. 8).

\section{Discussion}

It seems that each group of scholars, previously reviewed, has its criteria or standards of authenticity and each has a specific context in which they try to situate authenticity within that particular context with certain references in mind. It seems to be a shared view that authenticity takes its meaning from the particular social or 
cultural context in which it is situated, and it is from within that context that the attempt to study it scientifically has been undertaken. Differences in defining authenticity depend on the perspective from which the concept is viewed. Any definition of authenticity must be taken in context.

Within the argument that authenticity is context-dependent, Kramsch (1993) had a useful discussion of the various possible meanings of the word authenticity depending on the context where authenticity is situated. So, in this respect, for instance, she pointed that we have to distinguish between the context of language-learning activity and the context of language-using activity. This is supported by Widdowson (1990, p. 45) who contended that inauthentic language-using behavior may well be an effective language-learning one. Kramsch, insisting on the kind of context in which language teaching and language learning take place, concluded that all pedagogy is an artifact of educational discourse (Kramsch, 1993, p. 184) and that we need to measure what goes on in the language classroom context, not against some problematically defined criteria of authenticity, but against whether communicative and cognitive goals are accepted as appropriate in particular educational context.

The conclusion we draw is that each scholar tries to locate authenticity in a particular context, so some think of authenticity as essentially residing in a text while others think of it as being, in some sense, conferred on a text by virtue of the use to which it is put by particular people in particular situations. When moving away from looking at the authenticity of texts toward considering the authenticity of language use, the question of relativity and interpretation arises. For example, Bachman (1990) argued that "instances of language use are by definition context dependent and hence unique” (p. 310). This is further elaborated by Stevenson (1985) who stated that

when one claims that this is real, another will quickly ask 'to whom, in whose eyes, where, when with what intent, at what level of proficiency, perceived level of proficiency, and so on?' It's a more or less affair, dependent upon this and that (...). (p. 43)

It may be deduced that authenticity of texts or materials can be clearly determined or grasped, but when we go beyond the text, authenticity is very much a matter of interpretation or interaction/response. If we persist in considering authenticity as an absolute notion or concept, we would be misled, especially by the relatively clear definition of materials authenticity. In the same respect, and within the framework of the communicative language methodology, it is assumed that what goes on in the classroom has to reflect "real life". All this gives rise to statements and comments, especially, by non-native speakers like teachers and educators or researchers, criticizing the applicability of that requirement.

\section{A New Approach to Authenticity}

Having situated authenticity in its wider ELT context as well as defined in its multidisciplinarity and reviewed its dominant trends found in the literature, now it is worth putting forward the new approach of authenticity that the present study adopts and justifying that adoption and supporting it by learning theories and principles. In fact as dealt with earlier, that authenticity is a linguistic phenomenon within ELT and it is one aspect of language in a particular context, it is generally associated with what we add to language input or rather how we handle it, i.e., how we shape it in order to function with language or use language as a means to an end in a personalized way. In ESP, it is even narrower and more focused than that. It is an aspect of the specificity of language methodology, content, and the process used in order to suit the ESP practitioners while interacting with language either while teaching or learning. 
Now to define more specifically what authentic materials may mean, they are all types of materials used to lead learners, business students in this case, forward towards a target situation, by all means and methods, in which they will reuse all that have been learnt or exposed to during the learning stage in their professional realities when graduated. Yet, what may characterize the typicality of these materials is that they are rather uniquely designed for that specific group of learners for which a specific course is exclusively prepared in order to reach specific targets within a specific time span. Another final tenet of these same authentic materials is that they are motivated by needs of the learners in that specific situation and may not be suitable to other people in another context.

To relate the discussion on authentic materials to the world of business, which is our major concern in this study, authentic business materials would be those special materials that are instructed to special learners of business in a special context, who are motivated in a special way and by special needs aiming to reach special targets in special areas within the world of business. This approach to authenticity may be justified by the following arguments:

(1) The conventional view of authenticity has been questioned for its suitability to meet learners' needs and their profile in general let alone in ESP in particular.

(2) The new approach of authenticity is inspired by two major trends on authenticity in general, the first is led by Widdowson who bases authenticity on learners' appropriate response and interaction with language. The second trend is headed by Hutchinson and Waters stressing the functional and practical notion of authenticity as well its relevance to the learners' subject specialism (field of study) and their needs.

(3) The new version of authenticity is informed by major findings of Second Language Acquisition (SLA) research such as notions of motivation, interaction, and input. These elements assume a great importance in language learning and thus are prioritized by the new approach of authenticity and are taken into account while devising specialized materials for business studies.

(4) According to the classical view, authenticity is considered a property of the native speaker. Now, the English language is no longer his, but it is rather an international property, especially that ESP learners are necessarily either English as second language (ESL) or English as a foreign language (EFL) learners who will communicate with non-native speakers.

(5) The classical view of authenticity mixes up genuineness with authenticity, which proved inefficient and brought about confusion. Yet, the new approach distinguishes between both of these elements and makes them separate but complementary at the same time and gives each one its importance that it merits.

\section{Conclusion}

Authenticity will always remain a matter of controversy because many educators, teachers, and researchers differentiate in approaching this concept. As mentioned in the literature survey mentioned in the paper, there seems to be much less agreement about what constitutes authenticity. There are also many views about the different types of authenticity. Having subjected this concept to research and criticism, it sounds that its meaning and significance depend on the context where it is used and it is there it assumes some certain relevance. Nevertheless, the fact that the concept has been used and generalized in many disciplines implies its importance and value. It can be clearly seen that the researcher of the present study, despite its theoretical aspect, has put forward an alternative approach to authenticity and has provided the rationale for it. 


\section{References}

Adorno, W. T. (1973). Negative dialectics. London: Routledge \& Kegan Paul Ltd..

Allwright, R. (1979). Abdication and responsibility in language teaching. Studies in Second Language Acquisition, $2,105-121$.

Asher, J. J. (1977). Learning another language through actions. The complete teacher's guide book (6th ed.). Los Gatos, CA: Sky Oaks Productions, Inc..

Bachman, L. (1990). Fundamental considerations in language testing. Oxford: Oxford University Press.

Bacon, S. (1992). Authentic listening in Spanish: How learners adjust their strategies to the difficulty of the input. Hispania, 75(2), 398-412.

Bacon, S., \& Finnemann, M. (1990). A study of the attitudes, motives and strategies of university foreign language students and their disposition to authentic oral and written input. The Modern Languages Journal, 74(4), 459-473.

Bandler, R., \& Grinder, J. (1975). The structure of Magic I: A book about language and therapy. Palo Alto, CA: Science and Behavior Books.

Bendix, R. (1992). Diverging paths in the scientific search for authenticity. Journal of Folklore Research, 29(2), 103-132.

Benson, P. (1997). The philosophy and politics of learner autonomy. In P. Benson \& P. Voller (Eds.), Autonomy and independence in language learning (pp. 18-34). London, UK: Longman.

Bhatia, V. K. (1994). Generic integrity in ESP. In R. Khoo (Ed.), ESP: Problems and prospects. Singapore: SEAMEO RELC.

Black, H. C. (1968). Black's law dictionary: Definitions of the terms and phrases of American and English jurisprudence, ancient and modern (4th ed., p. 168). St. Paul, Minnesota: West Publishing Company.

Boud, D. (Ed.). (1988). Developing student autonomy in learning. New York: Kogan Press.

Breen, M. P. (1985). Authenticity in the language classroom. Applied Linguistics, 6(1), 60-70.

Brown, G., \& Yule, G. (1983). Discourse analysis. London: Longman.

Brumfit, C. J., \& Johnson, K. (1979). The communicative approach to language teaching. Oxford: Oxford University Press.

Candlin, C. N., \& Breen, M. (1979). Evaluating, adapting and innovating language teaching materials. In On TESOL '79: The learner in focus. Washington: TESOL.

Chomsky, N. (1965). Aspects of the theory of syntax. Cambridge, Massachusetts: MIT Press.

Clarke, D. F. (1989). Communicative theory and its influence on materials production. Language Teaching, 22(2), 73-86.

Dumitrescu, V. (2000). Authentic materials. ELT Forum, 38. Retrieved from http://exchanges.state.gov/forum

Duranti, L. (1989). Diplomatics: New uses for an old science. Archivaria, 28, 12.

Duranti, L. (1991). Diplomatics: New uses for an old science. Part V. Archivaria, 32, 7-24.

Fernàndez-Toro, M., \& Jones, F. R. (1996). Going solo: Learners' experiences of self-instruction and self-instruction training. In E. Broady \& M. Kenning (Eds.), Promoting learner autonomy in university language teaching (pp. 185-214). London: Association for French Language Studies in Association with the Centre for Information on Language Teaching and Research.

Flexner, S. B. (Ed.). (1993). Random house unabridged dictionary (2nd ed.). New York: Random House.

Gattegno, C. (1972). Teaching foreign languages in schools: The silent way (2nd ed.). New York: Educational Solutions.

Grellet, F. (1981). Developing reading skills. Cambridge: Cambridge University Press.

Guillot, M. (1996). Resource-based language learning: Pedagogic strategies for Le Monde sur CD-ROM. In E. Broady \& M. Kenning (Eds.), Promoting learner autonomy in university language teaching (pp. 139-158). London: Association for French Language Studies/CILT.

Harmer, J. (1983). The practice of English language teaching. London: Longman.

Hopkins, K. (1998). Educational and psychological measurement and evaluation. Englewood Cliffs, NJ: Prentice Hall.

Howatt, A. (1984). A history of English language teaching. Oxford: Oxford University Press.

Hutchinson, T., \& Waters, A. (1987). ESP: A learning centred approach. Cambridge: Cambridge University Press.

Hymes, D. (1971). Competence and performance in linguistic theory. In R. Huxley \& E. Ingram (Eds.), Language acquisition and methods. New York: Academic Press.

Kramsch, C. (1993). Context and culture in language teaching. Oxford: Oxford University Press.

Krashen, S. (1989). We acquire vocabulary and spelling by reading: Additional evidence for the input hoypothesis. The Modern Language Journal, 73, 440-464.

Lee, W. Y. (1995). Authenticity revisited: Text authenticity and learner authenticity. ELT Journal, 49(4), 323-328.

Linder, P. (2000). Is a negotiated syllabus feasible within a national curriculum?. In M. P. Breen \& A. Littlejohn (Eds.), The process syllabus: Negotiation in the language classroom (pp. 94-107). Cambridge: Cambridge University Press. 
Little, D. (1991). Learner autonomy 1: Definitions, issues and problems. Dublin: Authentik.

Little, D. (1997). Responding authentically to authentic texts: A problem for self-access learning?. In P. Benson \& P. Voller (Eds.), Autonomy and independence in language learning (pp. 225-236). London: Longman.

Little, D. (1999). Autonomy in second language learning: Some theoretical perspectives and their practical implications. In C. Edelhoff \& R. Weskamp (Eds.), Autonomes fremdsprachenlernen (pp. 22-36). Ismaning: Hueber.

Lozanov, G. (1978). Suggestology and outlines of suggestopedia. New York, London, Paris: Gordon and Breach.

McGarry, D. (1995). Learner autonomy 4: The role of authentic texts. Dublin: Authentik.

Mishan, F. (2005). Designing authenticity into language learning materials. Bristol, UK: Intellect Books.

Morrow, K. (1977). Techniques of evaluation for a notional syllabus. London: Royal Society of Arts.

Nunan, D. (1989). Designing tasks for the communicative classroom. Cambridge: Cambridge University Press.

Peacock, M. (1997). The effect of authentic materials on the motivation of EFL learners. English Language Teaching Journal, 51(2), 144-156.

Peacock, M. (1998). Usefulness and enjoyableness of teaching materials as predictors of on-task behaviour. TESL Journal [Internet], 3(2). Retrieved from: http://www-writing.berkeley.edu/TESL-EJ/ej10/a3.html

Porter, D., \& Roberts, J. (1987). Authentic listening activities. In M. L. Long (Ed.), Methodology in TESOL. Rowley, Mass.: Newbury House.

Pugh, S. M. (1996). Testament to Ruthenian: A linguistic analysis of the Smotryc'kyj variant. Cambridge: Harvard University Press.

Pulverness, A. (1999). Context or pretext, cultural content and the coursebook. Folio, Journal of the Materials Development Association MATSDA, 5(2), 5-9.

Rosenberg, N. V. (1993). Introduction to transforming tradition: Folk music revivals examined (pp. 1-26). N. V. Rosenberg (Ed.). Urbana: University of Illinois Press.

Schmidt-Rinehart, B. C. (1997). Authentic materials and Mexican immersion: A professional development program combining pedagogy, language, and culture. Foreign Language Annals, 30(2), 201-210.

Spelleri, M. (2002). From lessons to life: Authentic materials bridge the gap. ESL Magazine, 5(2), 16-18.

Stevenson, D. K. (1985). Authenticity, validity, and a tea party. Language Testing, 2, 41-47.

Swaffar, J. (1985). Reading authentic texts in a foreign language: A cognitive model. The Modern Language Journal, 69(1), 16-32.

Sweet, H. (1899). The practical study of languages. London: Oxford University Press.

Titone, R. (1968). Teaching foreign languages: An historical sketch. Washington: Georgetown University Press.

Tubtimtong, W. (1994). The problems of translating communicative needs into course design and implementation. In R. Khoo (Ed.), The practice of LSP. Anthology Series 34. Singapore: RELC.

Weijenberg, J. (1980). Authenticity of spoken language in textbooks for German as a foreign language. Heidelberg: Julius Groos Verlag.

Widdowson, H. G. (1978). Teaching language as communication. Oxford: Oxford University Press.

Widdowson, H. G. (1979). Explorations in applied linguistics. Oxford: Oxford University Press.

Widdowson, H. G. (1990). Aspects of language teaching. Oxford: Oxford University Press.

Wilkins, D. A. (1976). Notional syllabuses. Oxford: Oxford University Press. 